\title{
Analysis of anti tax avoidance in the company law personality denial
}

\author{
system \\ Xu Qingqing \\ Law school, Oxbridge College ,Kunming University of Science and Technology, \\ Yunnan ,650106,China
}

Keywords: anti-circumvention law personality deny tax analysis system

\begin{abstract}
: with the development of the society, the rapid economic progress, our country enterprise development more and more quickly, the company gradually increased number, the development of the company and business has become more complex. Internal shareholders of company personality will appear some improper behavior, the establishment of the company law personality system constraints of this kind of thing from happening. As a kind of realization of fairness and impartiality legal measures, research its application in the anti-circumvention tax is particularly important. Based on the overview of disregard of corporation law and its significance of understanding, through the study of its related properties, analyses the corporate personality system in the application of evading taxes.
\end{abstract}

\section{Overview of the meaning of corporate personality system and its function}

In order to realize the fairness and impartiality of the enterprise distribution, establish corresponding company law personality denial system in our country. Company law personality denial system in limiting shareholders abusing independent company personality and its associated co., LTD has played a role, and distribution of creditor's rights and the social public interest in the company security provides certain protection effect. Company law personality system in the main function is to deny the company and independent personality and limited liability of shareholders, in particular event, the body of the specified event related personnel responsible for the company's debt and credit information, responsible for the social and public interests.[1]

The origin of the company law personality denial system is based on a legal case in the United States, this case finally by European countries to follow, gradually recognized by relevant laws in our country and use. The establishment of the company law personality denial system in a certain sense, perfect the company system in China, in a certain sense, safeguard the legitimate rights and interests of the creditors and safeguard the public interest, in the legal system of other assisted to better promote the formation of social justice. Under the present social development, companies in the real interests driven many shareholders in the company for their own interests by unfair means persecution of other staff, or abusing the company personality and limited liability company for tax evasion. The persecution of the company relevant personnel not only interests, at the same time, a certain amount of damage to society and country. Make the company lose independent legal personality. Therefore the establishment of the company law personality denial system in the company's debt disputes, distribution and beneficial to the company debts, fundamentally analyze the company shall be investigated for legal responsibility.

Company law personality denial system since established in our country law is widely used.This system not only is involved in the civil lawsuit, has been employed in the social public 
welfare and environmental protection.First of all, the establishment of the company law personality denial system can improve the system of the company in a certain sense, constraint shareholder power.Some shareholders subverted the use of corporate personality and responsibility for tax evasion behavior such as illegal, use improper means to seek personal gain for themselves.The implementation of the company law personality denial system consolidate the defects of the independence of corporate personality and limited liability.The company legal person system is perfect, the company established the system of play a positive role.Second, the implementation of this system has protected the legitimate rights and interests of creditors.Found that shareholders when the company creditors to illegal profit when can Sue to the shareholders according to the company law personality denial system, to maintain their own interests, shall be investigated for their responsibility, and to a certain extent, save the loss of the company, safeguard legitimate rights and interests of creditors.Company law personality denial system is not only beneficial to improve the system of the company, the protection of rights and interests of creditors, and to a certain extent, also promoted the development of the social equity and justice.Company law personality denial system in a certain sense, which ensures that the company running fair conditioning to misconduct, in a sense of maintaining social justice, to the realization of social fairness has a certain role in promoting.

\section{Company law personality denial system in anti-circumvention tax applies}

The traditional company management and other related laws and regulations, the company law and tax law there is no better combined, but the company law personality denial system is just done precisely that.In the company's organization form, rules and regulations, management needs to the company law, the company as the main body of market economy, the establishment of the company law has become an important part of the market economy law, in China's contemporary economic system occupies an extremely important position. The company's independent personality can also be in the market competition of which has its legal liability.But many companies in the market and competitive modern can occupy a place, and gain more interest, to take in tax levy tax evasion behavior, such as a serious breach of our country law affect social order, such behaviour took advantage of the company, creditors, relatively independent of the relationship between shareholders and company law and tax law cannot better ties.So in terms of law should not only intensify company for social responsibility, avoiding the phenomenon of tax evasion, within the company should also make the company, shareholders and other shoulder their responsibilities, achieve the company's assets allocation fairness.[2]

Fine if the company law personality denial system is refers to the relevant national authority in the corporation in order to prevent illegal behavior using the company's independent personality, or use of loopholes denied the responsibility between company and fixed.Under normal circumstances, the company and the company's shareholders to the company's operations and activities must have the responsibility, but cannot avoid the phenomenon of avoid responsibility, and corporate personality denial system is key to social peace fair the establishment of a system.Our country and by the company law revised in 2005 will be a system in place, and in the law clearly established the independence of corporate personality, of shareholders and the company needs to bear the responsibilities, and provisions of the shareholders of what behavior belongs to the scope of the fraud, better distribution clearly define the responsibility of the company.Company law personality denial system is mainly for legitimate companies, determine the responsibilities of the shareholders, protection of rights and interests of relevant personnel, and maintain social interests.Corporate tax levied in our country, still there are some imperfect aspects.Especially in the actual holding 
company and the company undertake the liability of each shareholder has great unpredictability and uncertainty. This cause serious damage to the social stability and development of market economy in our country, such as company tax evasion behavior and the use of unfair means for malicious competition between companies, the use of legal loophole harm creditors all these serious influence our country law and order.So the company law personality denial system has a certain role in the anti tax avoidance, has the positive significance.It not only clearly should assume the responsibility of the company and shareholders, avoid malicious competition between companies, more in balance has a great effect on the shareholders and creditors' obligations

The establishment of the company law personality denial system is establishing the system of tax tax relationship of era development.It meets the requirement of tax debt relation, protect the lawful rights and interests of the creditors of weak, the establishment of this system in order to realize fair distribution company's interests, prevent shareholders abuse of persecution of creditors' interests.In the aspect of civil and commercial law, the system can effectively solve the debts of the relations between and among shareholders company creditors.In terms of tax in our country, the company law personality denial system can be better to perform the duties of the company's public service.

The legitimacy of social law personality system in suitable for anti-avoidance primary embodied in tax better implementation.Promoting better coordination of fixed interest and social interest.In the course of the activities of the company, and the relationship between the most closely is the relationship between the shareholders and creditors of the company.Shareholders as the company's investors, enjoy certain preferential treatment, the shareholders in the process of investment has certain risk, if the investment risk of external, will add pressure to creditors of risk bearing, and for a long time cause the interweavement of infringement of the right of creditors.Company law personality denial is the use of corporation personality to avoid shareholders violations of the creditors' interests, against the aim of the company, further influence the social harmony.So as to avoid the situation, to protect the interests of the creditors, the shareholders should be taken to deny its law personality means, to realize the aim of the company and the unity of the social interest.In tax revenue relations point of view, have the right to compulsory according to regulations of the state to the corporate tax, the tax is not on the basis of the contract, is produced on the basis of the law, is the enterprise should take responsibility to society, taxpayers have to pay tax to the state of the debtor.In fact, in the process of company's business within the law, shall have the right to must reduce tax, but if the company and shareholders to reduce the negative tax to use unfair means, countries have right to driving rights according to law personality denial system.Special need to be sure, the tax debt creditor's rights of company and the national tax is a kind of property distribution in the form of a cash flow relations, embodied in the debtor will be in the form of cash to countries.Although this kind of money in the form of transfer did not go into the market economy, but they are used in the construction of public facilities and public consumption.On the basis of the company law personality denial system in the application of anti tax avoidance has legitimacy.Besides revenue, according to the functions of everybody is different, and different income, formulate relevant regulations, maximum limit to realize the fair tax burden, under a variety of legal, fair treatment to every citizen's tax, is the country as creditors must do.That is a fair tax relations is not only for the taxpayer, and in view of the state and taxpayers, tax relationship between the state agencies.Fair tax mainly is to prevent excessive tax burden for the enterprise, the tax is unfair, cause social instability, not infringe upon the taxpayer personality, harm taxpayers to survive.If a taxpayer use company law personality to escape the social obligation to pay taxes will be lot of damage to the company, for serious affect the country's fiscal revenue, 
endangering social stability and development, to produce more unnecessary disputes.[3]

Company law personality denial system applied in the field of anti-avoidance, some scholars for its execution sceptical attitude, some scholars believe that this company shareholders use personality to accumulate wealth for improper behavior or tax evasion or commercial competition belongs to individual behavior, etc.The trading main body has nothing to do with interest income and the company, so the company law personality denial system exists some irrationality.Also the scholar thinks, improper behavior has been the company to keep out of shareholders, countries should rip the camouflage, for accountability to shareholders.Although different scholars have a different attitude to the company law personality denial system, but it's not hard to see, solve the problem of shareholders with company law personality violations are very concern.Nowadays the threshold of the company set up in the company law in our country is low, form company deals in the market for China's economic development is more and more complex, thus caused the shareholders in tax evasion form variety, and the situation is becoming more and more serious.Should be based on the actual situation in our country, combined with relevant academic point of view in the law on anti tax avoidance. Thus company law personality denial system in the application of anti tax avoidance is an alternative.

\section{Anti tax avoidance in the use of company law personality denial system should solve the problem}

In the process of the use of corporate personality system, the system must be clear on what is main body, clear whether the system in the management of the company and management performs the function of resource allocation, and should be observed in the corresponding field, whether the system design of the main body by a third party.The so-called third party mainly refers to the real master of the company's equity side, creditors, the court, etc.Substance control side is actually in the event of illegal behavior of the shareholders, creditors, refers to the cooperation with the company's investors, and the court is located right in the middle of a fair and just.

In addition to the clear system for the main body, should also be clear in the process of system implementation procedures, when moving company law personality denial system should follow the procedure related factors mainly have two aspects, one is, in the relevant tax authorities investigating the company's tax behavior, the need to have enough evidence to prove that the company has illegal and criminal behavior, and forensic investigation procedure shall be in strict accordance with legal procedures.Secondly, the tax authorities in China in addition to the proposed method to the company personality denied claims, in special cases also have the right to exercise the system directly.[4]

When tax authorities to implement the company law personality denial system, shall specify the system to adapt to the conditions, the first thing you need to clear is the system using the object, the object mainly have two aspects, on the one hand is the abuse of violation of party, another is the creditor of infringement.You need the clear system for behavior, it is mainly aimed at the behavior of the company shareholders abusing independent company personality.Finally still need to pay attention to whether the result of the infringement national tax rights and interests, if because shareholders abusing independent company personality and is directly related to infringement of rights and interests is damaged, then as the state organs have the right under the condition of evidence play its functions.

Tax liability distribution companies and individuals concerned shall bear the legal responsibility, and the allocation principles mainly include the following aspects, first, the principle of tax liability allocation in line with the actual transaction.Actual transaction principle is to ensure 
the company's independent personality assume corresponding responsibility further check the company whether there is any unreasonable behavior, and check whether there is tax evasion in corporate tax.Second, what is a reasonable business purposes, in any enterprise in the operation of the business practices in reasonable circumstances, has not reasonable business purposes, the company in the process of the cloud, investigate the tax authorities have the right to the company.

\section{Summarize}

To better implement company and social fairness, country according to the basic situation and set up the company law personality denial system.This system is applicable in anti-avoidance has certain necessity and irreplaceability.The performance of tax is the social responsibility, but for people of different income and ability, the size of the scope of the tax is also different.Fair tax can realize social fair, further promote social stability, and for a social good.Against the existence of the company, such as tax evasion behavior affect the rights and interests of creditors, harm social harmony.Used in anti tax avoidance in the company law personality denial system and its necessary, it is on the basis of the guarantee creditor rights and interests are not violated, further promote the harmonious development of society.

\section{References}

[1] shao-ying Chen. Theory of company law personality denial system applicable in the anti-avoidance [J]. Journal of jurists, 2011, 12:78-86 + 177 .

[2] Shi Hongbing. Company law personality denial system applicable in the anti-avoidance [J]. Chinese and foreign entrepreneurs, 2015:159-160.

[3] Gu Qian. Theory of company law personality denial system applicable in the anti-avoidance [J]. 2015,45: 241.

[4]XiaoXuePing. Existing problems and countermeasures in our anti-avoidance work [J]. Journal of gansu science and technology aspect. 2005 (3) 